\title{
Perceived Effect of Boko-Haram Insurgency on Means of Accessing Cowpea from North-East Nigeria to Bodija Market, Ibadan, Oyo State, Nigeria
}

\author{
O. J. Aluko' , B. Osikabor ${ }^{1}$, A. A. Adejumo², S. Sumade1 \\ ${ }^{1}$ Forestry Research Institute of Nigeria, Jericho, Ibadan, Nigeria \\ ${ }^{2}$ Department of Agricultural Extension and Rural Development, University of Ibadan, Ibadan, Nigeria \\ Email: juliwal2002@yahoo.com
}

Received 3 June 2016; accepted 19 June 2016; published 23 June 2016

Copyright (C) 2016 by authors and OALib.

This work is licensed under the Creative Commons Attribution International License (CC BY). http://creativecommons.org/licenses/by/4.0/

(c) (i) Open Access

\section{Abstract}

Boko-Haram insurgency has drastically affected the supply and distribution of agricultural produce especially Cowpea from the Northeast Nigeria to the markets in southern part of Nigeria due to unwillingness of traders to embark on journey to the troubled zone for fear of attack from the insurgency. This study investigated the perceived effect of Boko Haram on available means of getting the stock from the trouble zone to the Bodija markets Ibadan, Oyo State, Nigeria. All data were described and inferential statistics was employed to analyze the hypotheses. The finding revealed that the majority of the respondents were male in their active age and had more than 15 years experience in the cowpea marketing. Age $\left(P=0.013, \chi^{2}=16.169\right)$, Tribe $\left(\chi^{2}=11.220, \leq 0.05\right)$, Education $\left(\chi^{2}=17.049, \leq 0.05\right)$, Experience in marketing $\left(\chi^{2}=27.455, \leq 0.05\right)$, means of accessing cowpea from insurgence zone to market $(r=-0.241, \leq 0.05)$ were significantly related to perceived effect of Boko-Haram insurgency on means of accessing cowpea among traders. The study concluded that the insurgence had a detrimental effect on means of accessing cowpea from the troubled zone to Bodija market. Therefore, the need to intensify efforts in curbing the menace by the government and formulation of policies that will discourage terrorism were advocated for reducing the effect insurgency on means of accessing cowpea and other food crops from the north to zones in the country.

\section{Keywords}

Boko Haram, Cowpea, Access, Market, Perceived Effect, North East Nigeria

Subject Areas: Agricultural Science, Marketing

How to cite this paper: Aluko, O.J., Osikabor, B., Adejumo, A.A. and Sumade, S. (2016) Perceived Effect of Boko-Haram Insurgency on Means of Accessing Cowpea from North-East Nigeria to Bodija Market, Ibadan, Oyo State, Nigeria. Open Access Library Journal, 3: e2723. http://dx.doi.org/10.4236/oalib.1102723 


\section{Introduction}

Cowpea is one of the food consume by virtually every one in Nigeria. Both the rich and poor in the country believed that it is highly proteinous as well as easily affordable compared to all other food protein in the market. Cowpea is an important crop which plays a significant role in the diets of Nigerians. It serves as a major source of protein in the absence of sufficient animal protein for the population. Every Nigerian eats cowpea and the per capita consumption is about $25 \mathrm{~kg}$ to $30 \mathrm{~kg}$ per annum [1]. Cowpeas are grown widely in savannah regions of the tropics and sub tropics, especially in western and central African countries. Corroborating this assertion, [2] reported that $64 \%$ of cowpea grown in west and central Africa accounts for $80 \%$ of total production in Africa.

In many parts of West Africa, including Nigeria, cowpea seeds are prepared and taken in various forms. It can be made into different kinds of food; a very good example is steamed cowpea paste called "moinmoin" among others. It is a pudding made by steaming batter made with wet-milled beans, usually eaten as the protein component (i.e. meat substitute) of a meal with a carbohydrate and a source or condiment. In Nigeria, cowpea is known by different names in all the zones in the country: "Ewa" in Yoruba language, "Wake" in Hausa language and "Akidi" in Igbo language. Unlike other legumes, such as soybeans and groundnuts which are oilprotein seeds, cowpeas are starch protein seeds offering a wider pattern of utilization than any other legume in Africa.

According to [3] the bulk of cowpea production is done in the Northern region of Nigeria; the zone is primarily Sahel and Semi-arid Savannah that features low annual rainfall. The northern region of the country provides a significant proportion of foodstuffs to the southern part. Justifying this, [4] affirmed that nearly 50\% of foodstuffs consumed by the South are produced in the Northern states. The typical types of crops grown are grains (sorghum, millet and rice), legumes (cowpeas and groundnuts), vegetables (tomatoes, onions and peppers) and cotton. The major ethnic groups in the northeast states are the Kanuri, the Fulani and the Bwatiye.

However, a major challenge faced by the zone in recent times is that of the Boko-Haram insurgency, thus, making agricultural investments difficult in such a politically volatile environment. Sequel to this, there has been reduction in supply of cowpea to other zones in the country. Since July 2009, more than 5000 people have been killed in bombings and gun attacks by Boko Haram, an extremist Islamist group from North-Eastern Nigeria whose avowed aim is to overthrow the secular government in Nigeria and impose an Islamic state governed on the basis of Sharia law [5].

More so, the scope of the operation of the Boko-Haram sect has gone beyond civilian targets including Police and Military establishments. Boko Harma activities have disrupted the supply and distribution of inputs and outputs creating price shocks and causing massive displacement of farm labour. Similarly, increasing spread of nefarious activities of the Boko Haram had led to destruction of lives and property as well as agricultural produce in northern part of the country. This is a serious issue that could not be dismissed with a wave of hand because the majority of the agricultural produce consumed by the southerners is produced by northerners. In relation to this, the Punch newspaper dated 23rd of august, 2013, reported a conflict between the Yorubas from South West and the Hausa traders from the North at Bodija market in Ibadan resulting into death of five persons. The attack on Hausas was as a result of the fourteen Yoruba traders that were slain on route to Northern state to purchase food items. The traders in Bodija market abandoned the troubled zone, paving way for the Hausa traders to bring in foodstuffs (especially cowpea) to Ibadan and sell at preferred prices. The fear of been attack has made other traders exercise fear in going for the same purpose to the zone; some have resorted to total withdrawal from the trade while few reluctantly embark on the journey which in turn, results in doubling if not tripling the price. From the foregoing, it is therefore pertinent to examine the perceived effect of Boko-Haram insurgency in accessing cowpea from North Eastern Nigeria to Bodija market. The findings from this study will proffer answers to the following research questions:

$>$ What are the socio economic characteristics of the respondent?

$>$ What are the means of accessing cowpea from the North East among traders in the study area?

$>$ What are the perceived effects of insurgency on cowpea traders in the study area?

\section{Methodology}

The study was carried out in Bodija market Ibadan. Ibadan is located at the interface of savannah and forest, the capital of Oyo State, is the third largest city in Nigeria by population after Lagos and Kano. Bodija market is located in Ibadan North Local Government area of Oyo State, Nigeria. It is about one kilometre from the University of Ibadan along the road to the State Government's Secretariat which is also about one kilometre away. It is 
the main recipient and distributor of foodstuff moved from different parts of northern states to Ibadan metropolis and some parts of the south west of Nigeria. Fifty percent (50\%) cowpea traders were randomly selected from a list of registered cowpea traders to give a total 110 respondents. Descriptive statistics such as frequency distribution, percentages and mean were used to analyze the personal characteristics of respondents, access to stocks and perceived effect of insurgency on cowpea traders. Chi square and Pearson Product Moment Correlation were employed for inferential statistics.

\section{Result and Discussion}

\subsection{Personal Characteristics of the Respondents}

Table 1 indicates that $69.1 \%$ of the respondents in the study area were males while $30.9 \%$ were female. This signifies that more males are into the business than females basically because of the intensive energy requirements nature of the work, travelling to get stock since females are much more responsible for domestic responsibilities, child welfare and other house cores in the family. The mean age was 33 years which suggests that most of the respondents were young and active. This is in accordance with the finding of [6] who reported a high level of involvement of middle age categories in trading. Furthermore, the results revealed that vast majority $(82.2 \%)$ of the traders were married. This implies that married people are more into the business of trading in the market. Furthermore, more than half (59.1\%) of the traders had secondary education while $33.6 \%$ and $7.3 \%$ had primary and tertiary education respectively. Majority (93.6\%) of traders in the study area were Yorubas. This could be assumed that the geographical location of the study area contributed to domination of Yorubas in the market. This collaborates with the finding of [7] who posited that nearly all the traders in Bodija market are Yorubas. The results also shows that majority $(86.4 \%)$ of the traders in the study area were well experienced in the business. This could be the reasons for their dissemination of adequate information about the cowpea business in the study area.

Table 1. Socio-economic characteristics of the respondents.

\begin{tabular}{|c|c|c|}
\hline Variables & Frequency & Percentage $\%$ \\
\hline \multicolumn{3}{|l|}{ Sex } \\
\hline Male & 76 & 69.1 \\
\hline Female & 34 & 30.9 \\
\hline Total & 110 & 100.0 \\
\hline \multicolumn{3}{|l|}{ Age } \\
\hline $20-30$ & 9 & 8.2 \\
\hline $31-40$ & 47 & 42.7 \\
\hline $41-50$ & 35 & 31.8 \\
\hline 50 above & 19 & 17.5 \\
\hline Total & 110 & 100.0 \\
\hline \multicolumn{3}{|l|}{ Marital status } \\
\hline Widow(er) & 5 & 4.5 \\
\hline Single & 8 & 7.3 \\
\hline Married & 90 & 82.2 \\
\hline Divorced & 7 & 6.0 \\
\hline Total & 110 & 100 \\
\hline \multicolumn{3}{|l|}{ Education } \\
\hline Primary education & 37 & 33.6 \\
\hline Secondary education & 65 & 59.1 \\
\hline Tertiary education & 8 & 7.3 \\
\hline Total & 110 & 100.0 \\
\hline \multicolumn{3}{|l|}{ Tribe } \\
\hline Hausa & 7 & 6.4 \\
\hline Igbo & 0 & 0.0 \\
\hline Yoruba & 103 & 93.6 \\
\hline Total & 110 & 100.0 \\
\hline \multicolumn{3}{|l|}{ Experience } \\
\hline $1-5$ & 3 & 2.7 \\
\hline $6-10$ & 6 & 5.5 \\
\hline $11-15$ & 6 & 5.5 \\
\hline 15 above & 95 & 86.3 \\
\hline Total & 110 & 100.0 \\
\hline
\end{tabular}

Source: Field Survey, 2015. 


\subsection{Means of Accessing Cowpea among Respondents}

Table 2 shows that majority (99.1\%) of the traders in the study area do get cowpea through middlemen who are familiar with the zone since inception of Boko-Haram insurgence so as to enable them to continue their business. This is in line with [8] who reported that indirect selling could be through intermediaries such as distributors or agents. In addition, about $99.1 \%$ of the traders opined that they get cowpea through motorists who ply the road and the zone regularly. This according to them is a safe means of getting cowpea from the trouble zone even though there could be delay and scam in stock delivery yet; they are forced to continue with this means of getting cowpea because they don't want to quit the business like most of their colleagues. Also, $80 \%$ of the Cowpea traders in Bodija market merged together and send volunteer members to get stock for them. It is assumed that the majority preferred to send volunteer members who understand Hausa culture, language, and terrain of the northern part of Nigeria. This will give the volunteers upper edge to communicate with people over there in case of any attack. The use of mobile phone was another means preferred by most (78\%) of the traders. This could be attributed to its ease and safety as it does not involve going to the trouble zone for transaction. The study further revealed that majority (75\%) of the respondents boycotted the cooperative groups in getting cowpea. This could be attributed to factions among the groups.

Table 2. Distribution on means of accessing cowpea among traders.

\begin{tabular}{ccc}
\hline Means & No (\%) & Yes (\%) \\
\hline Through middlemen & 0.9 & 99.1 \\
Some traders merge together and send volunteer member(s) to get stock for them & 0.0 & 60.0 \\
Through cooperative groups & 75.0 & 32 \\
Online transaction & 0.9 & 78.0 \\
Through motorist plying the zone & 99.1 \\
\hline
\end{tabular}

Source: Field Survey, 2015.

\subsection{Perceived Effect of Boko-Haram Insurgence on Access to Cowpea among Traders}

Flunctuation in prices due to insurgence, unwillingness of the traders to embark on business trip to trouble zone and traders quiting the business for another were ranked to be the highest perceived effect on the traders with the mean of 3.0 respectively. It was revealed that the price of cowpea has not been stable since the inception of BokoHaram activities thus resulting in unwillingness of the people to carry out their businesses in the troubled zone. This is in line with [9] who reported that since the inception of the Boko Haram menace, prices of the affected agricultural produce coming from the North have hiked due to scarcity. The fear of been attacked and killed had made cowpea traders to feel reluctant to embark on business trip to northern part of the country. This could be responsible for traders quitting the business for another riskless traders which will not involve travelling and depending on the trouble zone for business.

It was also revealed from the study that cowpeas are very difficult to access due to Boko Harma activities. This was ranked second by the respondents in the study area with the mean value of 2.98 . This can be attributed to inability of farmer in the troubled zone to get their produce to market gate for business. Another perceived effect identify with the mean value of 2.92 form the study was reduction in man power for production resulting from insurgency. The insurgency had made most farmers and labourers to flee to from trouble zone. The shortage of manpower has contributed negatively to cowpea production in the trouble zone thus making the business not to be lucrative to the traders. Middlemen are very useful instrument in getting stocks to the southern part of the country from the north. This has drastically reduced since inception of Boko Harma as a result of displacement of dwellers who serves as a link between farmers and traders. It was assumed that most of the middlemen have left the trouble zone which they believed are not safe for businesses'.

Destruction of farm lands was ranked last with mean value of 2.73. This has altered agricultural activities in the zone as well as regular supply of cowpea to the market in the other parts of the country.

In summary, Table 3 shows that insurgency had a high effect on it was discovered that the perceived effect of Boko-Haram insurgency on traders in the market is high and had contributed to slow pace of cowpea trade in the study area (Table 4). 
Table 3. Categorization of perceived effect Boko-Haram insurgence on means of accessing cowpea.

\begin{tabular}{ccc}
\hline Effect & Frequency & Percentage (\%) \\
\hline Low & 2 & 1.8 \\
High & 108 & 98.2 \\
Total & 110 & 100 \\
\hline
\end{tabular}

Source: Field Survey, 2015.

Table 4. Distribution by perceived effect of Boko-Haram insurgence on access to cowpea among traders.

\begin{tabular}{|c|c|c|c|}
\hline & Undecided \% & Disagree \% & Agree \% Mean \\
\hline $\begin{array}{c}\text { Displacement of dwellers (middlemen) } \\
\text { who serves as a link between farmers and traders. }\end{array}$ & 8.2 & 0.0 & $91.8 \% 2.83$ \\
\hline Cowpea is not easily accessible during the insurgency. & 1.8 & 0.0 & 98.22 .98 \\
\hline Fluctuation in price due to insurgence. & 0.0 & 0.0 & 100.03 .00 \\
\hline Destruction of many farmland at the production zones. & 11.8 & 0.0 & 88.22 .76 \\
\hline Unwillingness of the traders to embark on business trip. & 0.0 & 0.0 & 1003.00 \\
\hline Reduction in man power for production resulting from insurgency. & 6.4 & 0.0 & 93.62 .92 \\
\hline Some traders are quiting the business for another. & 0.0 & 0.0 & 100.03 .00 \\
\hline
\end{tabular}

Source: Field Survey, 2015.

\subsection{Relationship between Socio-Economic Characteristics and Perceived Effect of Boko-Haram Insurgence on Access to Cowpea}

Table 5 shows that there was a significant relationship between age $\left(P=0.013, \chi^{2}=16.169\right)$, tribe $\left(P=0.024, \chi^{2}\right.$ $=11.220)$, education $\left(P=0.002, \chi^{2}=17.049\right)$, experience $\left(P=0.000, \chi^{2}=27.455\right)$ and perceived effect). This suggests that each of age, level of education and years of experience in trading had influence on their dispositions towards the effects of the insurgence on means of getting cowpea from the troubled zone to the market.

Table 5. Chi square analysis showing the relationship between socio-economics characteristics of cowpea traders and perceived effect of Boko-Haram insurgence on access to cowpea.

\begin{tabular}{cccc}
\hline Variables & $\chi^{2}$ & df & $P$ Value \\
\hline Age & 16.169 & 6 & 0.013 \\
Tribe & 11.220 & 4 & 0.024 \\
Education & 17.049 & 4 & 0.002 \\
Experience & 27.455 & 6 & 0.000 \\
\hline
\end{tabular}

\subsection{Relationship between Means of Accessing Cowpea and the Perceived Effects of Boko-Haram Insurgence}

Table 6 shows that significant relationship exists between perceived effect of Boko-Haram insurgence and means of getting the stocks $(r=-0.241, P \leq 0.05)$. This implies that as the intensity of Boko-Haram insurgency increases, the means of getting cowpea from the farm gate to the market decreases.

Table 6. Correlation analysis showing the relationship between means of accessing cowpea and the perceived effects of Boko-Haram insurgence.

\begin{tabular}{ccc}
\hline Variable & Correlation Coefficient & P-value Decision \\
\hline Mean of accessing cowpea \& perceived effect of insurgency & -0.241 & $0.000 \mathrm{~S}$ \\
\hline
\end{tabular}

${ }^{*}$ Correlation is significant at the 0.05 level. 


\section{Conclusion}

Boko Haram has succeeded in instilling fear and interring communal hatred among the people who have been doing business together in peace and harmony for decades. Traders in Bodija markets now fear to embark on business trip to the troubled zone for their normal business trip while many others have abandoned the business for another which has drastically affected the cowpea business in the market.

\section{Recommendation}

Based on the findings of this study the following recommendations were prescribed.

1) Traders in Bodija market should liaise with their counterpart in the zone for easy transportation of stocks to southern zone to ease the problem been faced in getting the stock to the market.

2) Adequate information on insurgency activities should be gathered by traders before making any transaction in order not to fall victim of losing their life's and cash.

3) Government should intensify effort in curbing the menace and formulate policies that will discourage terrorism so as to reduce the effect insurgency on agricultural activities.

\section{References}

[1] Falusi, A.O. (1997) Agricultural Development and Food Production in Nigeria: Problems and Prospects. In: Shaib, B., Adedipe, N.O., Aliyu, M. and Jir, M., Eds., Integrated Agricultural Production in Nigeria: Strategies and Mechanisms, NARP Monograph No. 5, 151-170.

[2] Singh, B.B., Mohan Raj, D.R., Dashiell, K.E. and Jackai, L.E.N. (1997) Advances in Cowpea Research. Copublication of International Institute of Tropical Agriculture (IITA) and Japan International Research Center for Agricultural Sciences (JIRCAS). IITA, Ibadan, Nigeria.

[3] Petu-Ibikunle, A.M., Abba-Mani, F. and Odo. P.E. (2008) Determination of Rate and Time of Nitrogen Application on Cowpea Variety in the Sudan Savannah Zone. International Journal of Academic Focus Series, 1, 13-21.

[4] Bizwatch Nigeria (2013) Boko Haram Food Insecurity. http://bizwatchnigeria.ng/boko-haram-and-food-insecurity/

[5] Agbiboa, D.E. and Maiangwa, B. (2013) Boko Haram and Current Religious Violence in Nigeria: Towards a NonKilling Approach. Journal of Developing Societies, 29, 379-403. http://dx.doi.org/10.1177/0169796X13503198

[6] Adekoya, A.E. (2009) Food Insecurity and Coping Strategies among Farming Households in Oyo State, Nigeria. Journal of Food Agriculture and Environment, 7, 187-191.

[7] Lawal, R.A. (2014) Socio-Economic Effect of Boko Haram Violent on Oyo State, Nigeria. Journal of Humanities and Social Science, 19, 61-65.

[8] Kotler, P., Armstrong, G., Saunders, J. and Wong, V. (2002) Principles of Marketing. 3rd European Edition, PrenticeHall, London.

[9] Orhero, A.E. (2015) The Economic and Security Implications of Boko Haram Terrorism. International Journal of African and Asian Studies, 10, 6-11. 